[10] Cardoso, J. de F., Casarotto Filho, N., Cauchick Miguel, P. A. (2015). Application of Quality Function Deployment for the development of an organic product. Food Quality and Preference, 40, 180-190. doi: https://doi.org/10.1016/j.foodqual.2014.09.012

[11] Telezhenko, L., Dzyuba, N., Kashkano, M. (2015). Instant porridge composition of the functional purpose: technological aspects. Food Science and Technology, 9 (4), 68-73

[12] Bravo-Núñez, Á., Gómez, M. (2019). Physicochemical properties of native and extruded maize flours in the presence of animal proteins. Journal of Food Engineering, 243, 49-56. doi: https://doi.org/10.1016/ j.jfoodeng.2018.09.005

[13] Telezhenko, L. M., Dzyuba, N. A., Kashkano, M. A., Valevska, L. O. (2016). Osnovy naukovykh doslidzhen. Kherson: Hrin D.S., 192.

[14] Jozinović, A., Šubarić, D., Ačkar, Đ., Babić, J., Miličević, B. (2016). Influence of spelt flour addition on properties of extruded products based on corn grits. Journal of Food Engineering, 172, 31-37. doi: https://doi.org/10.1016/j.jfoodeng.2015.04.012

[15] Mardar, M., Tkachenko, N., Znachek, R., Leonardi, C. (2017). Optimization of formulation composition of the crispbread with improved consumer properties. Technology Audit and Production Reserves, 2 (3 (34)), 22-29. doi: https://doi.org/10.15587/2312-8372.2017.99941

[16] Dzyuba, N., Telezhenko, L., Kashkano, M., Vikul, S., Priss, O., Zhukova, V. et. al. (2018). Development of recipes and estimation of the nutrient composition of cardio-protective fresh-mixes. EUREKA: Life Sciences, 1, 46-53. doi: https://doi.org/10.21303/2504-5695.2018.00548

[17] Belitz, H.-D. et. al. (2009). Food Chemistry. Springer-Verlag Berlin Heidelberg, 1070.

[18] Velisek, J. (2014). The Chemistry of Food. Wiley, 1125.

[19] Simpson, B. K. (Ed.) (2012). Food Biochemistry and Food Processing. Wiley, 900. doi: https:// doi.org/10.1002/9781118308035

\title{
INVESTIGATION OF TECHNOLOGICAL PROPERTIES OF FOUR-TYPE TRITICALE SEED OF DIFFERENT FRACTIONS
}

\author{
Vitalii Liubych \\ Department of seed storage and processing technology \\ Uman National University of gardening \\ 1 Institutska str., Uman, Ukraine, 20305 \\ LyubichV@gmail.com \\ Volodymyr Novikov \\ Department of seed storage and processing technology \\ Uman National University of gardening \\ 1 Institutska str., Uman, Ukraine, 20305 \\ 1990vovanovikov1990@gmail.com \\ Iryna Polianetska \\ Department of genetics, plants' selection and biotechnology \\ Uman National University of gardening \\ 1 Institutska str., Uman, Ukraine, 20305 \\ polyanetska@ukr.net \\ Serhiy Usyk \\ Department of general agriculture \\ Uman National University of gardening \\ 1 Institutska str., Uman, Ukraine, 20305 \\ sewooborot@gmail.com
}


Vasyl Petrenko

Laboratory of flour-grinding, peeled grain and bakery production Institute of food resources of National Academy of agrarian sciences 4a E. Sverstuk str., Kyiv, Ukraine, 03041 vasylpetrenko07@gmail.com

\section{Svitlana Khomenko}

The V. M. Remeslo Myronivka Institute of Wheat of National Academy of Agrarian Sciences of Ukraine

68 Tsentralna str., Tsentralne, Kyiv region, Ukraine, 08853

homenko.mip@ukr.net

Victor Zorunko

Department of plants' protection, genetics and selection Odessa State agricultural experimental station of National Academy of Agrarian Sciences of Ukraine

24 Majatska road, Khlibodar, Bilyavsky district, Odessa region, 67667 zorunko1@gmail.com

\section{Oleksandr Balabak}

Sector of plants' genetics, selection and reproductive biology National dendrological park "Sofiyivka" of National Academy of Agrarian Sciences of Ukraine 12 A Kyivska str., Uman, Ukraine, 20300 o.a.balabak@ukr.net

Valentyn Moskalets

Selection-technological sector

Institute of Horticulture of the National Academy of Agrarian Sciences

23 Sadova str., Novosylky, Ukraine, 03027

moskalets7819@i.ua

Tetiana Moskalets

Selection-technological sector

Institute of Horticulture of the National Academy of Agrarian Sciences

23 Sadova str., Novosylky, Kyiv region, Ukraine, 03027

shunyascience@ukr.net

\section{Abstract}

Triticale is a promising agricultural crop. The increased content of protein, balanced by the amino acid composition, advantageously distinguishes triticale seed for peeled grains and food concentrates production. Seed cleaning is an important technological operation of food productions, but setting regimes of seed-cleaning equipment for processing triticale seed need specification today.

The aim of this work is to study geometric and physical characteristics of four-type triticale seed and elaboration of recommendations as to its cleaning and fractionating.

There was studied the fractional composition of four-type triticale seed. The comparative analysis of its length, width and thickness in samples of different sorts and fractions was realized. The dependence of geometric properties of triticale seed on sort is reliable. Fractionating reliably influences the change of the mass index of 1000 seeds, changing from $65,2 \mathrm{~g}$ to $25,8 \mathrm{~g}$. The mass index of 1000 seeds essentially differs between studied sorts.

Such properties are inherent to seed fractions, obtained by a sieve of 3,2-20 $\mathrm{mm}$ and 3,0-20 $\mathrm{mm}$, that are recommended to be called big seeds. Fractions, obtained by a sieve of 2,0-20 and 2,2-20 are analogously similar. Properties of the middle fraction, obtained by sieves of 2,4-20; 2,6-20; 2,8-20 essentially changed, depending on sort. 
The elaborated recommendations may be used at choosing cleaning regimes for triticale seed on sieve and sieve-air separators.

Keywords: triticale, technological properties of seed, mass of 1000 seeds, seed fractions.

\section{Introduction}

Widening of the food products assortment is one of most priority tasks under conditions of the modern market environment. The increase of purchasing ability of consumers and intensive development of technologies has favored the development of the competitive environment. New food products can be obtained as a result of using innovative techniques of raw material processing, able to minimize losses of nutritive and biologically active elements. At the same time it is expedient to use little-spread types of raw materials, especially triticale seed.

The planting area of triticale seed grows annually. Although its ancestors (sp. Triticum, $s p$. Secale) are intensively used in the human food ration, a role of the crop itself remains undefined [1].

Intensification of the selection work with triticale seed is connected with its valuable agricultural parameters $[2,3]$. Triticale is able to form stable harvests on low-quality soils, including fields with uneven reliefs [4]. It is rich in healthy elements $\mathrm{Ca}, \mathrm{Mg}, \mathrm{P}, \mathrm{Cu}$ i $\mathrm{Zn}$ [1].

Triticale seed occupies an intermediate position between wheat and rye by its technological properties, but its bakery qualities are low at the expanse of a low amount of cellulose [4]. An unsatisfactory quantity and quality of cellulose in triticale seed testify to a low content of gluten that widens usefulness of processed products of triticale seed for humans and in such a way increases its potential profitability [5].

The improvement of bakery properties is possible at the expanse of formation of compositional mixtures. High indices were fixed in triticale flour and one of hard mixtures of corn with non-transparent endosperm [6]. Triticale seed forms less particles comparing with soft and hard wheat at grinding that testifies to lower energy consumption for grinding [7].

Peeled grain products of triticale seed become also spread. Today there are known methods of triticale seed processing in shelled, comminuted, flattened peeled grains. Triticale is also a valuable ingredient of the wide assortment of food concentrates.

But the main processing method of triticale seed is forage production [8, 9].

So, triticale seed is a promising raw material for making food products. An important stage of it is seed cleaning. Taking into account the forage directionality of triticale seed usage, the question of its cleaning is urgent, so it is today expedient to study its properties deeply.

\section{Analysis of the literary sources and standing of the problem}

The seed mass contains admixtures of the organic and inorganic origin. An important quantity of admixtures shortens the seed storage duration without losses of its quality. At that admixtures favor the decrease of the working resource of seed shelling and seed grinding, and their presence in ready food products is strictly regulated by quality and safety standards.

A geometric characteristic of seed has an important value at corn cleaning. Seed release from admixtures, different by width, length and thickness is one of least expensive and most effective methods. That is why sieve and sieve-air separators are most spread in the seed processing industry, especially at initial seed processing.

One of rational methods of seed processing is its fractionating. It is noted in works [10-12], that technological properties of different seed fractions reliably differ. The grain-unit of the big fraction is $757 \mathrm{~g} / 1$, middle -746 , small $-684 \mathrm{~g} / 1$, and the mass of 1000 seeds - respectively $44 \mathrm{~g}$, 33 and $21 \mathrm{~g}$. 
The studies by G.A. Egorov [13] established that the content of endosperm in the big fraction is higher $(83,5 \%)$ comparing with the small one $(72,5 \%)$. The decrease of seed size essentially decreases the output of whole kernels as a result of the tunic number increase.

It was established [14], that the economic expedience of seed fractionating is possible only at the optimal process of shelling and usage of high-effective spreaders.

It was established, that fractionating of forage seed conditions obtaining up to $30 \%$ of seed, better by $2-3$ classes, that increases its total cost and raises the coefficient of expedient use, but fractionating is recommended to be conducted at the stages of bringing seed to basic conditions in elevators and centralized approach to this problem [15].

It was established, that separation of triticale seed in fractions and their separate processing in peeled grains conditions the efficiency increase of peeled grain production. But the question of purpose-oriented use of the fractional composition of triticale seed of new sorts at making peeled grain products of the high demand remains unsolved and needs complex studying [10-12].

The aim of the conducted studies was to specify geometric properties of triticale seed of different sorts that gives a possibility to set up the grain-cleaning equipment at primary processing effectively.

The following tasks were set for attaining this aim:

- to establish the change of geometric and physical parameters of triticale seed depending on sort;

- to elaborate recommendations as to fractionating triticale seed.

\section{Materials and methods}

\section{1. Raw material}

The research object was seed of four-type triticale of sorts Alkid, Strateg, Taktik, line LP 195 and Kharkiv Khlobodar. Triticale seed was cultivated in control identical conditions at the experimental plot of the Uman National University of gardening (Ukraine) under conditions of the Right-bank forest-steppe of Ukraine. The precursor - occupied fallow. Introduction of fertilizers: nitric $-120 \mathrm{~kg} / \mathrm{he}$, phosphoric and potassium $-60 \mathrm{~kg} / \mathrm{he}$.

\section{2. Research equipment}

Fractionating of flattening products was realized on the laboratory spreader RLU-1 (producer - Olis LTD, Ukraine) (Fig. 1). For separating intermediate products, there were used stamped sieves with orthogonal orifices. Sizes of the orifices were 3,2-20 mm;3,0-20 mm; 2,8-20 mm; 2,6-20 mm; 2,4-20 mm; 2,2-20 mm; 2,0-20 mm.

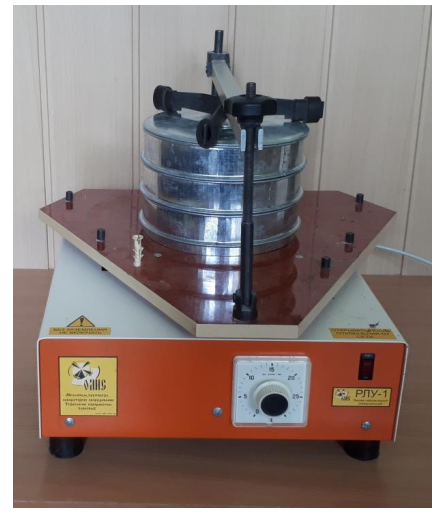

$a$

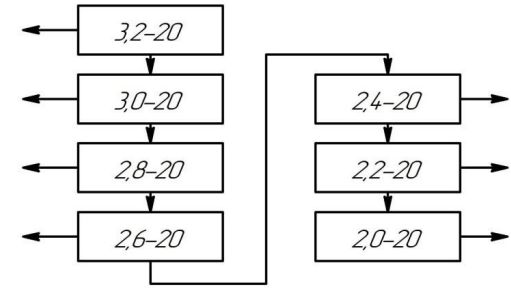

$b$

Fig. 1. Laboratory spreader RLU-1: $a$ - general outlook; $b$ - technological scheme

\section{3. Statistical processing of the obtained data}

The number of analytic reiterations is four. The results of analytic reiterations were processed by the methods of descriptive statistics using the programs Microsoft Excel 2010 and 
STATISTICA 10. The quality of the experiment was estimated by the value of the variation coefficient of samples, formed from the data of the analytic reiterations. The experiment was considered reliable at the unessential varying of the data of the analytic reiterations. The dependencies between the factors were determined by the method of dispersion and regression analysis. The choice of optimal processing methods was realized by interpolating samples of the experimental data, constructing a desirability function.

The advantage of using desirability diagrams is a possibility of deducing reliable tendencies and recommendations. The essence of the correspondent analysis is in comparison of all results of the statistical processing of regularities between factors and improvement criteria, construction of a complex function and search for its extreme values.

\section{4. Research program and methodology}

Triticale seed, stored under identical conditions, was used for the experiment. Its humidity was stable as $13,0 \pm 0,4 \%$. Mass of the sample for the analysis $-200 \mathrm{~g}$. Fractionating was realized by the formula, presented on Fig. 1. The per cent content of fractions (x) was determined by formula (1):

$$
\mathrm{x}=\frac{\mathrm{m} \times 100}{200}
$$

where $\mathrm{m}$ - fraction mass, $\mathrm{g}$.

\section{Results and discussion}

Triticale seed had different sizes and evenness depending on sort. It can be explained by the studied genetic peculiarities of triticale seed. Seed of the line LP 195 had the width by 0,2-0,3 mm more, comparing with other sorts of triticale seed (Fig. 2). The more thickness indices (by 0,1$0,2 \mathrm{~mm}$ ) were inherent to the sort Khlibodar Kharkivsky. The longest was seed of the sort Alkid. That is why the difference of geometric sizes of triticale seed between sorts must be taken into account at the primary cleaning of raw materials and formation of triticale seed lines.

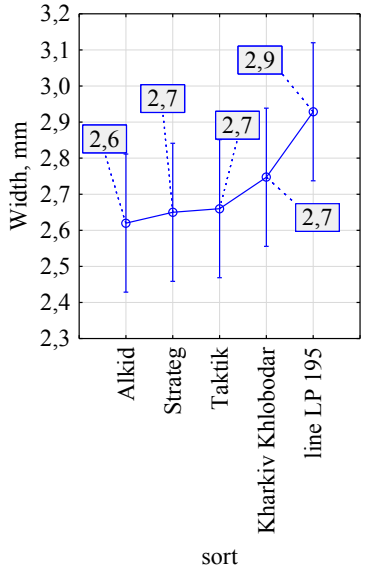

$a$

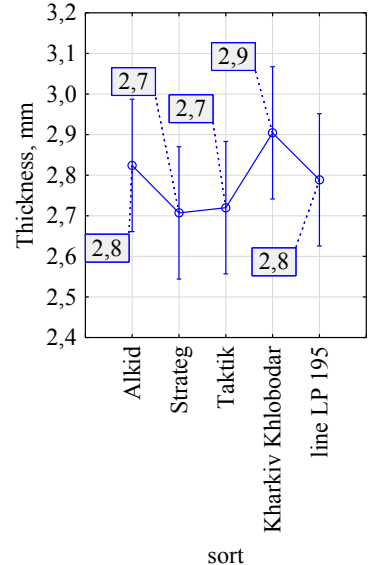

$b$

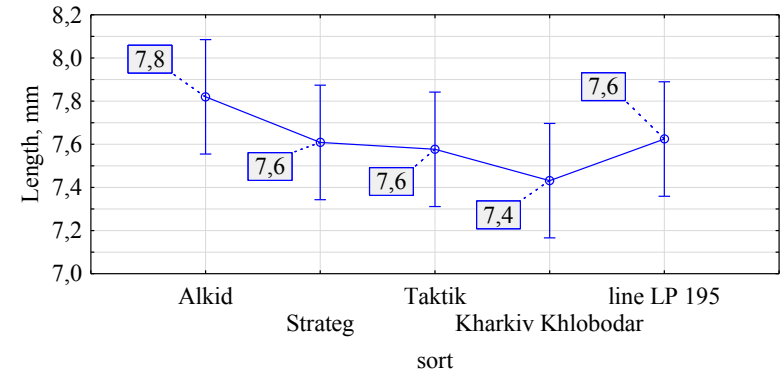

$c$

Fig. 2. Change of geometric sizes of seed depending on sort: $a$ - seed width; $b$ - seed thickness;

$$
c \text { - seed length }
$$

The change of geometric sizes of seed influenced the mass of 1000 seeds that essentially influences the technologic process at producing flour and peeled grains. It has been established, that the most mass of 1000 seeds was inherent to the sort Strateg, at that it had average statistical geometric sizes comparing with the other sorts (Fig. 3). It can be explained by the wrinkled structure of triticale seed tunics that is its natural property. 

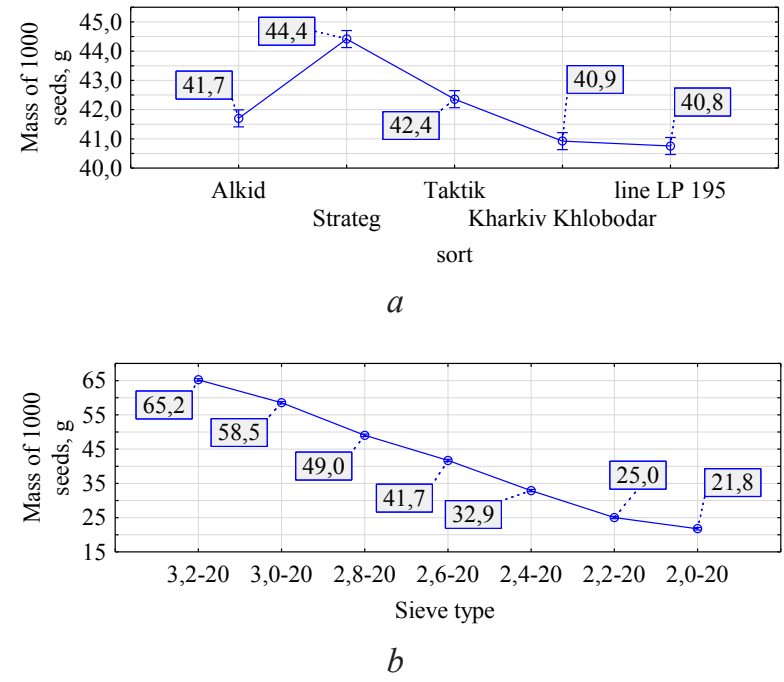

Fig. 3. Change of the mass of 1000 seeds depending on sort and fractional composition: $a$ - mass of 1000 seeds of different sorts; $b$ - mass of 1000 seeds of different fractions

The decrease of the mass index of 1000 seeds from $65,2 \mathrm{~g}$ to $21,8 \mathrm{~g}$ as a result of the seed size decrease was prognosticated.

Taking into account peculiarities of the triticale seed construction, it was expedient to take into account the mass of 1000 seeds of epy correspondent fractions for searching the biggest and fullest seed (Fig. 4). Desirability criteria were the most length, width and thickness of seed and most mass of 1000 seeds.

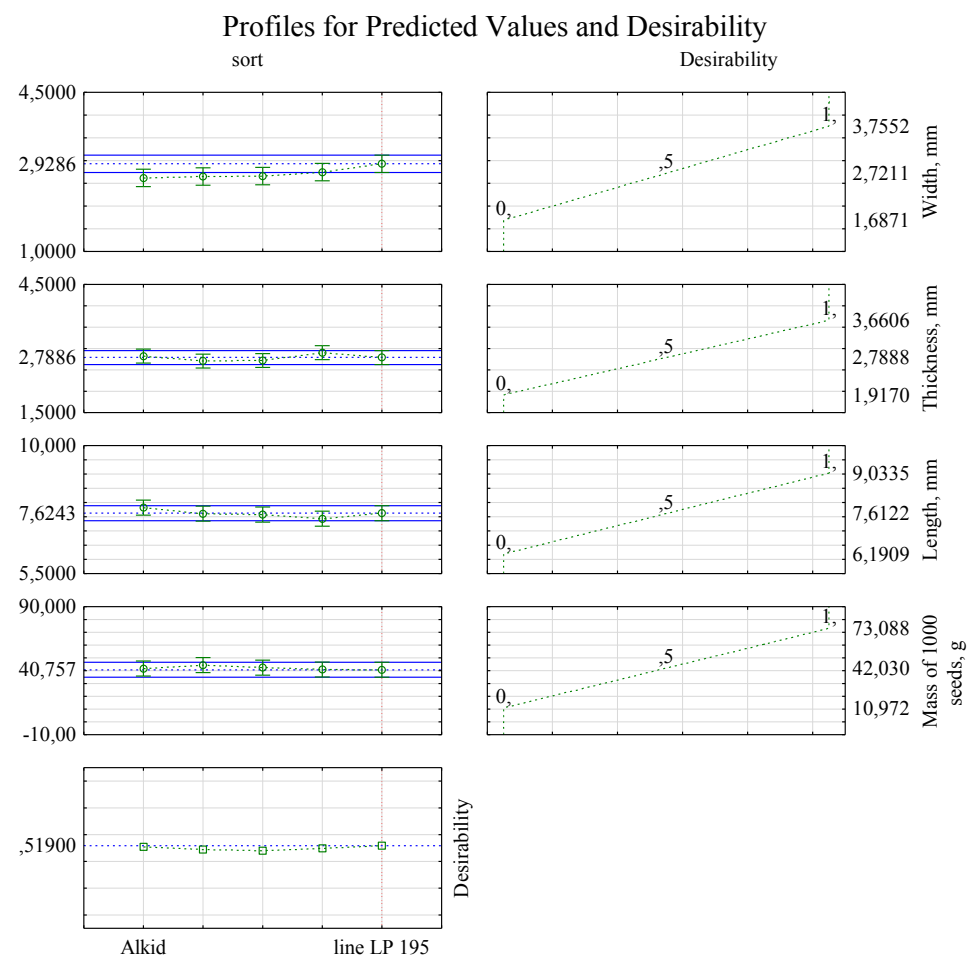

Fig. 4. Results of searching for the optimal sort by the parameter of size and fullness

According to the results of the search of the variant by the set criteria, the line LP 195 was accepted optimal. But the satisfaction level of the set criteria was rather low (52\%), that confirms the difference of geometric properties of the studied samples. 
The use of cluster analysis could help to classify sorts and fractions of triticale seed by the geometric signs. The most similar by the geometric properties and seed mass were the line LP 195 and Kharkiv Khlobodar (Fig. 5). Analogously similar were Alkid and Taktik. Strateg essentially differed by the correspondent parameters.

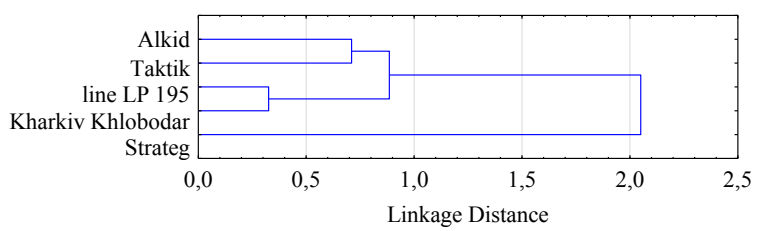

Fig. 5. Similarity of the sorts of four-type triticale by the geometric signs and mass of 1000 seeds

At studying the fractional composition of triticale seed of different sorts, there were revealed the similar properties in fractions, obtained by a sieve of 2,0-20 $\mathrm{mm}$ and 2,2-20 $\mathrm{mm}$ (Fig. 6). That is why it is recommended to combine the correspondent fractions for further processing.

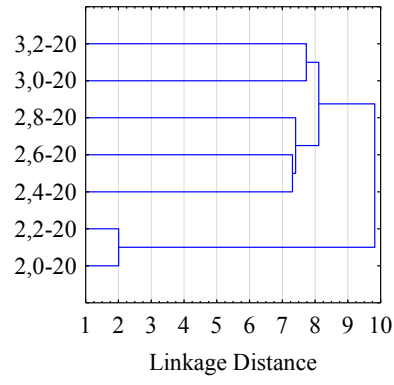

$a$

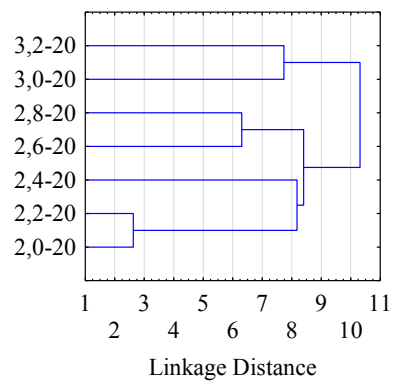

c

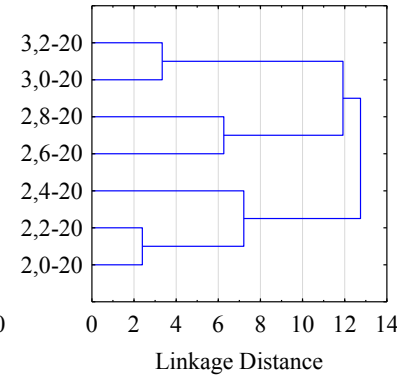

$b$

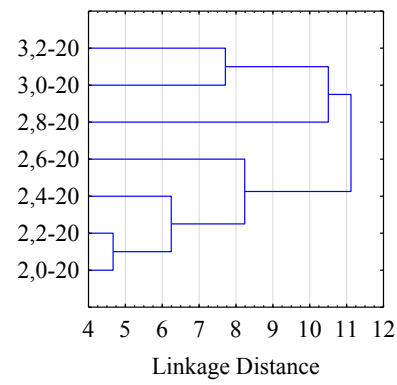

$d$

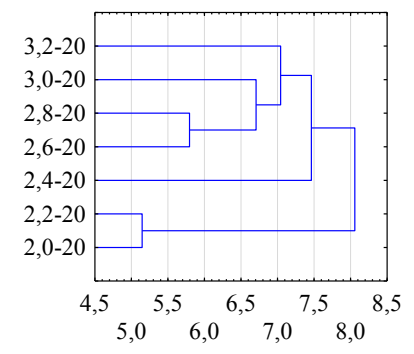

e

Fig. 6. Similarity of the geometric sizes of triticale seed of the different fractions: $a$-sort Alkid; $b$ - sort Taktik; $c$ - line LP 195; $d$-sort Strateg; $e$ - sort Kharkiv Klibodar

Among four-type triticale seed, big seed is considered as obtained by a sieve 3,0-20 mm and 3,2-20 $\mathrm{mm}$. The properties of the fractions, obtained by a sieve 3,0-20 $\mathrm{mm}$ and 2,4-20 $\mathrm{mm}$ essentially varied depending on sort. 


\section{Conclusions}

The length, width and thickness of triticale seed essentially depended on sort. The mass of 1000 seeds differed analogously depending on sort and was from $40,8 \mathrm{~g}$ to $44,4 \mathrm{~g}$. As a result of fractionating there takes place the variation increase of the mass index of 1000 seeds from $21,8 \mathrm{~g}$ to 65,2. The best geometric properties are inherent to the triticale line LP 195.

There has been scientifically grounded the expedience of triticale seed division in three fractions: big, middle and small. The big one includes seed, obtained by a sieve of 3,0-20 mm. The middle one consists of seed, obtained by sieve orifices of 3,0-20 mm and 2,2-20 mm. Small seed is from sieve orifices of 2,2-20 mm. It is expedient to eliminate the small fraction for using four-type triticale seed effectively.

The obtained results are expedient to be used for intensifying flour-grinding and peeled grain production. It is promising to study technological properties of the fractional composition of four-type triticale.

\section{References}

[1] Liubych, V. V., Novak, L. L., Voziian, V. V. (2018). Technological properties of winter triticale grain depending on the norms of nitrogen fertilizers. Journal of Uman National University of Horticulture, 92, 119-125.

[2] Adonina, I. G., Orlovskaya, O. A., Tereshchenko, O. Y., Koren, L. V., Khotyleva, L. V., Shumny, V. K., Salina, E. A. (2011). Development of commercially valuable traits in hexaploid triticale lines with Aegilops introgressions as dependent on the genome composition. Russian Journal of Genetics, 47 (4), 453-461. doi: https://doi.org/10.1134/s1022795411040028

[3] Salmanowicz, B., Langner, M., Wiśniewska, H., Apolinarska, B., Kwiatek, M., Błaszczyk, L. (2013). Molecular, Physicochemical and Rheological Characteristics of Introgressive Triticale/Triticum monococcum ssp. monococcum Lines with Wheat 1D/1 A Chromosome Substitution. International Journal of Molecular Sciences, 14 (8), 15595-15614. doi: https://doi.org/10.3390/ijms140815595

[4] Ittu, G., Saulescu, N., Ittu, M., Mustatea, P. (2014). Present and perspectives in Romanian triticale breeding program. Commun Agric Appl Biol Sci, 79 (4), 185-191.

[5] Pattison, A. L., Appelbee, M., Trethowan, R. M. (2014). Characteristics of Modern Triticale Quality: Glutenin and Secalin Subunit Composition and Mixograph Properties. Journal of Agricultural and Food Chemistry, 62 (21), 4924-4931. doi: https://doi.org/10.1021/jf405138w

[6] Del-Angel, A. R., Sotelo, A. (1982). Nutritive Value of Mixtures Using Chick-peas with Wheat, Triticale, Normal and Opaque-2 Corns. The Journal of Nutrition, 112 (8), 1474-1480. doi: https://doi.org/10.1093/ jn/112.8.1474

[7] Naik, H. R., Sekhon, K. S., Abbas Wani, A. (2010). Physicochemical and Dough-handling Characteristics of Indian Wheat and Triticale Cultivars. Food Science and Technology International, 16 (5), 371379. doi: https://doi.org/10.1177/1082013210366880

[8] Keese, C., Meyer, U., Rehage, J., Spilke, J., Boguhn, J., Breves, G., Dänicke, S. (2008). Ruminal fermentation patterns and parameters of the acid base metabolism in the urine as influenced by the proportion of concentrate in the ration of dairy cows with and without Fusariumtoxin-contaminated triticale. Archives of Animal Nutrition, 62 (4), 287-302. doi: https://doi.org/10.1080/17450390802066443

[9] Zuber, T., Maurer, H. P., Möhring, J., Nautscher, N., Siegert, W., Rosenfelder, P., Rodehutscord, M. (2016). Variability in amino acid digestibility of triticale grain from diverse genotypes as studied in cecectomized laying hens. Poultry Science, 95 (12), 2861-2870. doi: https://doi.org/10.3382/ps/pew174

[10] Haidai, H. S. (2012). Tekhnolohichni vlastyvosti zerna zalezhno vid rozmiru zernivky. Materialy Vseukrainskoi naukovoi konferentsiyi molodykh uchenykh. Uman, 183-185.

[11] Haidai, H., Matvienko, N., Bobko, T. (2011). Zalezhnist pokaznykiv yakosti zerna vid dozy mineralnoho zhyvlennia ta rozmiru zernivky. Osnovy biolohichnoho roslynnytstva v suchasnomu zemlerobstvi, 9, 446.

[12] Morhun, V. O., Voloshenko, O. S. (2012). Pidvyshchennia efektyvnosti pererobky zerna pshenytsi. Zb. nauk. prats Odeskoi NAKhT, 36, 25-29. pleks, 336

[13] Egorov, G. A., Petrenko, T. P. (1999). Tekhnologiya muki i krupy. Moscow: Izdatel'skiy kom-

[14] Vereshchynskyi, O. (2011). Chy potribno vyluchaty milke zerno pry provedenni sortovykh pomeliv pshenytsi. Hranenie i pererabotka zerna, 3, 20-21.

[15] Dmytruk, Ye. A. (2010). Shliakhy ratsionalnoho vykorystannia zerna. Fraktsionuvannia zerna. Pohlyblena pererobka zerna. Yakist ta bezpeka zerna, nasinnia ta zernoproduktiv. Atestatsiya vyrobnycho-tekhnichnykh laboratoriy: Mizh. nauk.-tekhn. konf. Kyiv, 26. 